\title{
PERCENTAGE OF SEGMENTED NEUTROPHIL IN INVAGINATION PATIENTS IN H. ADAM MALIK MEDAN HOSPITAL
}

KEY WORDS: Segmented Neutrophil, Invagination

\section{Syafed Rianda}

\section{Erjan Fikri*}

\section{R. Lia Kusumawati}

Resident Of Department Of Surgery, Faculty Of Medicine, Universitas Sumatera Utara

Consultant Of Pediatric Surgery, Department Of Surgery, Faculty Of Medicine, Universitas Sumatera Utara *Corresponding Author

Consultant Of Clinical Microbiology, Department Of Microbiology, Faculty Of Medicine, Universitas Sumatera Utara

INTRODUCTION: Invagination cases are cases of pediatric surgical emergencies that are very often encountered, where the most frequent complications are necrosis and perforation. For the digestive system which plays the most role as the immune system is neutrophils. Segmented neutrophils are full capacity active cells containing cytoplasmic granulomas and chromatin-rich hollow cell nuclei. Segmented neutrophils are associated with the body's defense against infection and inflammatory processes and are the first cells present when an infection occurs. The purpose of this study is to assess the percentage of segmented neutrophil in invaginated patients at. H. Adam Malik Medan Hospital.

METHOD: This research is a descriptive design study, which was carried out in the Division of Pediatric Surgery, Department of Surgery H. Adam Malik Medan Hospital, by collecting samples from invagination patients' medical records starting from January 2016 to December 2018 that met the inclusion and exclusion criteria. Data processing is performed using statistical software SPSS programs in the form of tables or diagrams.

RESULTS: There were 23 study samples with a mean sample age $\leq 1$ year, and the majority were male with 15 patients $(65.21 \%)$. In this study, the average percentage of segmented neutrophil in patients with invagination in H. Adam Malik Medan Hospital is $62.93 \%$. Segmented neutrophils $\geq 70 \%$ had a lower proportion of 9 patients (39.13\%) compared to segmented neutrophils $<70 \%$ of 14 patients $(60.87 \%)$.

CONCLUSION: The mean percentage of segmented neutrophil in patients with invagination at the H. Adam Malik Medan Hospital is $62.93 \%$.

\section{INTRODUCTION}

Invagination cases are pediatric surgical emergency that are very common. Where the most frequent complications are intestinal necrosis and perforation. Intestinal necrosis and perforation in children is one of the causes of abdominal emergencies requiring immediate surgery. It is reported that $30-75 \%$ of children have perforated intestine at the first time they are diagnosed (Bansal, 2012).

The incidence of this disease is not known with certainty. This disorder is commonly found in children under 1 year and its frequency decreases with age. Invagination is generally found more often in men with a ratio between men and women 3: 2 (Sapan, 2007). Invagination that occurs in premature babies, often lead to a misdiagnosis with necrotizing enterocolitis (NEC), causing wrong or delayed management of surgical interventions (Jeffrey,2003).

Rotavirus infection causes lymphadenopathy and thickening of the distal ileal wall which can lead to invagination Julie, 2005). Typical symptoms of rotavirus infection include watery diarrhea, fever, abdominal pain, and vomiting that cause dehydration. In 2007 a study was carried out in Yogyakarta about diarrhea and the results obtained $60 \%$ of diarrhea caused by rotavirus (Soenarto, 2009).

For the digestive system which plays the most role as the immune system is neutrophils. The main function of neutrophils is phagocytosis. Neutrophils can recognize pathogens directly. Bonding with pathogens and phagocytosis can increase if antibodies or complement that function as opsonin are bound. Without the help of specific antibodies, complement in serum can precipitate protein fragments on the surface of the pathogen making it easier to be bound by neutrophils and phagocytosis. Segmented neutrophils are associated with the body's defense against infection and inflammation and become the first cell that is present when an infection occurs (Bratawidjaja, 2010).
Many patients come late to the hospital, obstruction in the intestine that caused by invagination can cause a very distended abdomen so that at the time of examination it is difficult to feel a tumor mass, therefore for the diagnosis must hold to the symptoms of invagination triad (Mac Mohan, 1991). Accompanied by laboratory tests on routine blood tests found an increase in the number of segmented neutrophils (> 70\%) (Ravitch, 2007).

Until now in Indonesia there has not been much research on segmented neutrophils in invaginated patients. Therefore, the researcher wants to see "Percentage of Segmented Neutrophils in Invagination Patients at H. Adam Malik Medan Hospital".

\section{METHODS}

This research is a descriptive study to see the percentage of segmented neutrophils in invagination patients at $\mathrm{H}$. Adam Malik Medan Hospital. This research was conducted in the Pediatric Surgery Division, Department of Surgery at the H. Adam Malik Medan Hospital. The time of the study was carried out after the research proposal was approved by the ethics committee by collecting samples from the medical records of invagination patients starting from January 2016 to December 2018 that met the inclusion and exclusion criteria.

The inclusion criteria in this study were: pediatric patients with diagnosis of invagination who had performed surgery at the H. Adam Malik Medan Hospital during the period of January 2016 to December 2018; and medical records with basic patient data, physical examination, investigations (segmented neutrophil), and intestinal viability (surgery report). Exclusion criteria in this study were patients aged $>$ 18 years.

Data processing is performed using statistical software SPSS programs in the form of tables or diagrams. Explanation of tables and diagrams will be presented in narrative form. 


\section{RESULT}

In this study found 23 cases of invagination carried out by laparotomy exploration through medical record data for 3 years from January 2016 - December 2018 that met the inclusion and exclusion criteria. The characteristics of this research sample can be seen in table 1 .

\section{Table 1. Characteristics of study samples}

\begin{tabular}{|l|c|c|}
\hline \multicolumn{1}{|c|}{ Characteristics } & $\begin{array}{c}\text { Mean (士SD) or } \\
\text { Median (Min-Max) }\end{array}$ & N (\%) \\
\hline Age (Months) & $21,73(3-43)$ & \\
\hline $\begin{array}{l}\text { Invagination } \\
\text { Location }\end{array}$ & & \\
\hline Ileocolica & & $13(56,5)$ \\
\hline Ileoileal & & $1(4,3)$ \\
\hline Ileocolocolica & & $3(13,0)$ \\
\hline Colocolica & & $2(8,7)$ \\
\hline Ileocaecal & & $1(4,3)$ \\
\hline Ileocololica & & $1(4,3)$ \\
\hline Ileocolica + Colocolica & & \\
\hline Leukocyte (/mm $)$ & $15.920(6.610-41.590)$ & \\
\hline $\begin{array}{l}\text { Segmented } \\
\text { Neutrophil (\%) }\end{array}$ & $62,93( \pm 11,72)$ & \\
\hline Electrolyte & & \\
\hline Sodium & $130,83(5,35)$ & \\
\hline Potassium & $3,66(0,86)$ & \\
\hline Chloride & $100,61(4,79)$ & \\
\hline Intestine Viability & & $11(47,8)$ \\
\hline Viable & & \\
\hline Non-viable & & \\
\hline
\end{tabular}

In terms of age, the mean age of patients with invagination was 21.73 months with the youngest age being 3 months and the oldest age was 43 months (Table 1). From the data above, based on the location of invagination, the majority were found in ileocolica in 13 patients $(56.5 \%)$. In terms of gender, this study shows the number of patients with invagination with male sex as many as 15 people $(65.21 \%)$ and women as many as 8 people (34.78\%).

Table 2. Description of the Study Sample Based on Segm ented Neutrophils

\begin{tabular}{|c|c|c|}
\hline Segmented neutrophils & Frequency & Percentage \\
\hline$\geq 70 \%$ & 9 & $39.13 \%$ \\
\hline$<70 \%$ & 14 & $60.87 \%$ \\
\hline Total & 23 & $100 \%$ \\
\hline
\end{tabular}

In this study, the average percentage of segmented neutr ophils in patients with invagination in H. Adam Malik Medan Hospital is $62.93 \%$. Of the 23 study samples obtained segmented neutrophils $\geq 70 \%$ as many as 9 patients $(39.13 \%)$ and segmented neutrophils $<70 \%$ were 14 patients $(60.87 \%)$ (Table 2).

\section{DISCUSSION}

\section{CHARACTERISTICS OF RESEARCH SAMPLES}

Invagination is one of the most common cases of surgical emergencies. Invagination found a condition where intestinal segments enter into other segments, at the time of laparotomy surgery. The incidence of this disease is not known with certainty. (Stringer, 1992).

According to gender, the results of this study were 23 invaginated children, in which 15 sample $(65.21 \%)$ were male and 8 sample (34.78\%) were female. In this study the number of invagination cases between men and women is different. From epidemiological data, it is said that invagination incidents are found more frequently in boys with a ratio between boys and girls 3:2 (Sapan, 2007).
From the results of this study invagination sufferers in the age group $\leq 12$ months generally suffer from invagination by 19 patients $(82.6 \%)$ and age $\geq 12$ months by 4 patients $(17.39 \%)$. This is supported by previous studies found children under the age of 1 year and the frequency decreases with increasing age (Sapan, 2007).

Invagination is divided according to location, which part of the intestine is involved (Pickering, 2007). From this study the majority location of invagination was found in ileocolica as many as 13 patients $(56,5 \%)$.

Stringer (1992), children who have a tendency to have abdominal pain comes repeatedly with an interval of 15-20 minutes. In general, during an episode of abdominal pain followed by vomiting of fluid and food. In invagination process that has not completely obstructed, the child still can defecate but usually occurs diarrhea or soft stool, then the stool mixed with fresh blood and mucus, then defecation is only in the form of fresh blood mixed with mucus without feces.

The results of this study illustrate the most cases found during surgery, with viable intestine of 11 patients $(47.82 \%)$. Invagination can result obstruction or strangulation of the intestine. In the process of invagination that has not completely obstructed, the child can still defecate but usually occurs diarrhea or soft stool, then the stool mixed with fresh blood and mucus, then defecation is only in the form of fresh blood mixed with mucus without feces (Stringer, 1992).

Invaginated patients with non-viable intestine were 12 patients $(52.17 \%)$. The majority of male sex with non-viable intestine were 8 people $(34.78 \%)$. This does not show significant results for assessing intestinal viability between viable and non-viable. This sudden obstruction will cause the apex section of the invagination to become edema and stiff, if this has happened then it is not possible for the non-viable portion of the intestine to return to normal spontaneously. If this condition continues, it would became toxic and disruption of arterial blood vessels, the segment involved intestinal necrosis, gangrene, perforation, diffused peritonitis, shock and death (Winset, 2004).

Jeffrey (2003) states that invagination often results in delays in diagnosis, causing delays in the handling of surgical interventions. In general, the longer the delay in diagnosis and the surgical procedure, the greater the possibility of poor intestinal viability. If the patient is late coming to the hospital, obstruction in the intestine caused by invagination can cause a very distended stomach. After 18-24 hours of the first abdominal pain episode, the intestine that had been partially blocked turned into a total blockage, followed by a growing process of edema, so the patient was seen with signs of obstruction, such as distended abdomen with a increased of intestinal peristalsis, green vomiting and dehydration. Nonviable risk in the intestine 24 hours after the onset of symptoms at least $20 \%$ (Ravitch,2007).

\section{SEGMENTED NEUTROPHIL IN INVAGINATION CASES}

The digestive system that plays the most role as the immune system is neutrophils. The main function of neutrophils is phagocytosis. Neutrophils can recognize pathogens directly. Bonding with pathogens and phagocytosis can increase if antibodies or complement that function as opsonin are bound. Segmented neutrophils are associated with the body's defense against infection and inflammation and become the first cell that is present when an infection occurs (Brataw idjaja, 2010).

In this study, the average percentage of segmented neutrophils in patients with invagination in H. Adam Malik Medan Hospital is $62.93 \%$. Segmented neutrophils $\geq 70 \%$ had a lower proportion of 9 patients (39.13\%) compared to 
segmented neutrophils $<70 \%$ of 14 patients $(60.87 \%)$. This is not in line with the results of previous studies where labor atory tests on blood are found to increase the number of segmented neutrophils (> 70\%) (Ravitch, 2007).

\section{CONCLUSION}

In this study, the average percentage of segmented neutrophils in patients with invagination in H. Adam Malik Medan Hospital is $62.93 \%$. Segmented neutrophils $\geq 70 \%$ had a lower proportion of 9 patients (39.13\%) compared to segmented neutrophils $<70 \%$ of 14 patients $(60.87 \%)$.

\section{REFERENCES}

1. Ashcraft, Gabriel, Catarina, \& Difiore, J.W. (2007). Intussusception. Seminars in Pediatric Surgery, vol. 8,No. 4,pp. 214-220.

2. Bainton, D.F., Ullyot, J.L., \& Farquhar, M.G. (1971). The Development of Neutrophilic Polymorphonuclear Leukocytes In Human Bone Marrow. J Exp Med, 134(4):907-34.

3. Fu, J.J., Baines, K.J., Wood, L. G., Gibson, P.G. (2013). Systemic Inflammation Is Associated With Differential Gene Expression And Airway Neutrophilia In Asthma. OMICS, 17(4):187-99.

4. Geneva:World Health Organization. (2002). Acute Intussusception In Infants And Children. Incidence, Clinical Presentation And Management: A Global Prospective.

5. Guarner,J., Deleon-Bojorge, B., Lopez-Corella, E., Ferebee-Harris, T., Goodig L., Garnett, C.T., Et Al. (2003). Intestinal Intussusception Associated With Adenovirus Infection In Mexican Children Am J Clin Pathol, 120(6):845-50.

6. Jawetz, Holloway, G., Coulson, B.S. (2013). Innate Cellular Responses To Rotavirus Infection.J Gen Virol, 94:1 151-1160.

7. Jawetz, E.A., Montgomery, \& Popek, E.J. (2005). Intussusception, Adenovirus, And Children: A Brief Reaffirmation. Human Pathology, vol. 25, no. 2, pp. 169-174.

8. Jeffrey, M., Soriano-Gabarr O., Grimprel, E., et al. (2009). Intussusception Among Young Children In Europe. Pediatric Infectious Disease Journal, vol. 25, no. 1, supplement, pp. S22-S29.

9. Mac, Mohan, Bines, J.E., Kohl, K.S., Forster, J., Zanardi, L.R., Davis, R.L., Hansen, J., et al. (2008). Brighton Collaboration Intussusception Working Group. Acute Intussusception In Infants And Children As An Adverse Event Following Immunization: Case Definition And Guidelines Of Data Collection, Analysis, And Presentation.

10. Philip, Kramarz, P., Ravitch, France, E.K., Destefano, F., Black, S.B., Shinefield, H., Ward, J.I., Chang, E.J., Chen, R.T., Shatin, D., Hill, J., Lieu, T., Ogren J.M. (2007). Population Based Study Of Rotavirus And Intussusception Pediatr Infection.

11. Ravitch, J. D., Atwell, D. Burge, \& Wright, D. (2007) Nodular Lymphoid Hyperplasia Of The Intestinal Tract In Infancy And Childhood. Journal of Pediatric Surgery, vol.20,no. 1,pp.25-29,2007.

12. Ravitch, Nathan, C. (2006). Neutrophils And Immunity: Challenges And Opportunities. Nature Reviews Immunology, 173-82.

13. Sapan, Pickering, Ivanoff, B., Justice, F., Mulholland, K. (2007). Clinical Case Definition For The Diagnosis Of Acute Intussusception. J Pediatr Gastro Nutr, 39:511-8.

14. Stringer, Ravitch, Bines, J.E., Ivanoff, B., Mulholland, K. (1992). Clinical Case Definition Diagnosis Of Acute Intussusceptions. Journal of Pediatric Gastroenterology and Nutrition, 39:51 1-8.

15. Su, Z., Mao,Y.P., OuYang, P.Y.,Tang, J., Xie, F.Y. (2015). Initial Hyperleukocytosis And Neutrophilia In Nasopharyngeal Carcinoma: Incidence And Prognostic Impact. PLoS One, 10 (9):e0136752.

16. Treaba, D. O., Khedr, S., Mangray. S, Jackson, C., Castillo,J.J.,Winer,E.S. (2012). Acute Myeloid Leukemia Evolving From JAK 2-Positive Primary Myelofibrosis And Concomitant CD5-Negative Mantle Cell Lymphoma: A Case Report And Review OfThe Literature. Case Rep Hematol

17. Winset, Bines, J.E., Kohl, K.S., Forster, J., et al. (2004). Acute Intussusception In Infants And Children As An Adverse Event Following Immunization: Case Definition And Guidelines Of Data Collection, Analysis, And Presentation. 